\title{
Laundry wastewater characteristics and their relationship with river water quality as an indicator of water pollution. Case study: Code Watershed, Yogyakarta
}

\author{
Galih Dwi Jayanto ${ }^{1}$, Margaretha Widyastuti ${ }^{2 *}$, M. Pramono Hadi² \\ ${ }^{1}$ Master Program on Planning and Management of Coastal Areas and Watersheds, Faculty of Geography, Universitas Gadjah Mada, \\ Special Region of Yogyakarta 55281, Indonesia \\ ${ }^{2}$ Department of Environmental Geography, Faculty of Geography, Universitas Gadjah Mada, Special Region of Yogyakarta 55281, \\ Indonesia
}

\begin{abstract}
Laundry services are rapidly becoming ubiquitous in rural and urban areas, generating high domestic waste volumes. Their growth has raised concerns about the quality of natural waters, particularly the rivers into which most laundry businesses discharge their wastewater. The research set out to study laundry wastewater characteristics and their relationship with the river water quality as water pollution indicators in Code Watershed (Indonesia). It lies in three administrative units where many human activities take place in the watershed's upper to the lower reaches. BOD and COD of 25 sampled laundry businesses were analyzed descriptively and compared to the laundry wastewater standards stipulated in Regulation No. 7 of 2016 and the class II water quality standards issued in Governor Regulation No. 20 of 2008. The results showed that the BOD of four laundry businesses and the COD of 18 laundry businesses exceeded the predetermined standards. Overall, rivers in Code Watershed meet the class II river water criteria for BOD at three of the seven sampling points and COD at all points.
\end{abstract}

\section{Introduction}

In the Special Region of Yogyakarta (SRY), Indonesia, increasing community activities along the Code River, mostly those of domestic and small-scale industrial sectors, have modified the water quality. Monitoring in 2013 confirms ammonia and COD are low at the inlet but high at the outlet, up to the point where the quality standards are exceeded. These findings indicate that the influence of waste disposal from, for instance, settlements, lodging, small-scale industries, and health services, becomes more significant downstream [1]. Meanwhile, another monitoring by the SRY Environment and Forestry Service reveals an increasing trend in detergent contents from 2017 through 2019 and 2020, above the class II water quality standards. A significant increase also appears in BOD. Accordingly, the source of pollutants in the Code River that passes through urban areas comes from domestic waste, e.g., greywater, soap, food wastes and scraps, and fecal wastes [2].

These contaminants can adversely affect river water and its surroundings, that the constantly decreasing water quality alters processes and mechanisms in abiotic, biotic, and social environments in Code River [3]. High nitrate and manganese concentrations indicate the abiotic environment's damaged functions, disrupting the other environmental constituents: reduced biota diversity and elevated community vulnerability to diseases caused by deteriorating river water quality and poor sanitation.
Laundry business constitutes a small-scale industry with a persistently growing number and economic significance in several countries, such as Indonesia, India, and China. Nevertheless, this industry's development raises various kinds of problems as it generates about 3.881 million liters of wastes per day, comprising $40 \%$ of the total industrial wastes, or 20,000-25,000 liters/person/year [4]. Meanwhile, in Turin, Italy, data shows that the laundry industry produces an average of $400 \mathrm{~m}^{3}$ of wastewater per day for every 15 liters of water used. Because the wastewater consists of organic substances (soap, detergents, chlorinated solvents, aromatics, biological substances, fats, and grease) and inorganic substances (heavy metals, sand, silt, clay, metal ions, and particles), it makes the refining process intricate and highly time-consuming [5].

With the increasing use of chemicals in the industry, river water pollution has quickly become an alarming issue [6]. The characteristics of laundry wastewater are divided into three types, namely domestic laundry, industrial laundry and hospital laundry [7] (Table 1). Based on the table, it is known that the distribution of wastewater quality levels from the three activities. Laundry wastewater from laundry services (industry) has a higher level than other activities.

In this study, only selected parameters were used for analysis, only parameters that had a high content in laundry wastewater were selected. Wastewater from laundry activities still contains high concentrations of

*Corresponding author: m.widyastuti@geo.ugm.ac.id 
dissolved materials (TSS), BOD, COD, and also LAS (linear alkylbenzene sulphonate) [8,9]. The COD and MBAS content after leaving the washing machine were $186-2418 \mathrm{mg} / \mathrm{L}$ and $25.0-33.9 \mathrm{mg} / \mathrm{L}$ decreased slightly to $122-14488 \mathrm{mg} / \mathrm{L}$ for $\mathrm{COD}$ and $6.50-10.3 \mathrm{mg} / \mathrm{L}$ for MBAS in water bodies/rivers [10].

Table 1. Characterisation of domestic,industrial and hospital laundries wastewater

\begin{tabular}{cccc} 
Parameters & $\begin{array}{c}\text { Domestic } \\
\text { laundry }\end{array}$ & $\begin{array}{c}\text { Industrial } \\
\text { laundry }\end{array}$ & $\begin{array}{c}\text { Hospital } \\
\text { laundry }\end{array}$ \\
\hline $\mathrm{pH}$ & $9.3-10$ & $9.0-11$ & $\begin{array}{c}11.4- \\
11.6\end{array}$ \\
\hline $\mathrm{EC}(\mu \mathrm{s} / \mathrm{cm})$ & $190-1400$ & $640-3000$ & $\begin{array}{c}808- \\
2000\end{array}$ \\
\hline $\mathrm{TDS}(\mathrm{mg} / \mathrm{L})$ & $400-6000$ & 420 & $456-800$ \\
\hline $\mathrm{TSS}(\mathrm{mg} / \mathrm{L})$ & $200-987$ & $400-1000$ & $66-71$ \\
\hline $\mathrm{TH}(\mathrm{mg} / \mathrm{L} \mathrm{CaCO} 3)$ & - & 44 & $53-68$ \\
\hline $\mathrm{TA}(\mathrm{mg} / \mathrm{L} \mathrm{CaCO} 3)$ & $83-200$ & 128 & $302-375$ \\
\hline $\mathrm{TOG}(\mathrm{mg} / \mathrm{L})$ & $8.0-35$ & $71.5-$ & \\
\hline Phosphate $(\mathrm{mg} / \mathrm{L})$ & $4-27.6$ & 3.43 & $10.8-167$ \\
\hline BOD5 (mg/L) & $48-1200$ & $218-9810$ & $44-50$ \\
\hline COD $(\mathrm{mg} / \mathrm{L})$ & $375-4155$ & 212000 & $477-876$ \\
\hline Turbidity $(\mathrm{NTU})$ & $14-400$ & $40-150$ & 87.9 \\
\hline
\end{tabular}

Source: (Lade \& Zainab, 2018)

Based on the background, the purpose of this study was to determine the characteristics of the laundry business wastewater and its relationship to the water quality of the Code river. Where the current development of the laundry business is very large and has the potential to pollute the river environment.

\section{Research Area Description}

Based on the inventory of laundry business locations in SRY, Code Watershed was selected as the research location because it is located in the middle of the region, dividing the City of Yogyakarta into two (Fig 1). It stretches as far as $45.58 \mathrm{~km}$, traversing three administrative units: from Sleman Regency (precisely, Merapi Volcano National Park in Hargobinangun, Pakem) to the City of Yogyakarta then Bantul Regency (i.e., Jl. Imogiri Timur, Trimulyo, Jetis). Two main rivers flow in the watershed, namely Boyong and Code. Based on public knowledge, Boyong starts from Merapi Volcano to J1. Ring Road Utara then continues downstream as Code River.

\section{Methodology}

The research began by taking 25 samples of laundry business wastewater and Code River water at ten observation points simultaneously. These samples were determined using purposive sampling, i.e., based on the distance between the laundry business and the river, while the observation points were selected based on the laundry sample density. The research tools included 500 $\mathrm{ml}$ water sample bottles to safely store and transport the collected water to the laboratory and a Global Positioning System (GPS) to determine the location. The laboratory analysis results were analyzed descriptively and compared with the wastewater standards and the class II river water quality standards based on the predetermined stream order. The parameters observed were Biological Oxygen Demand (BOD) and Chemical Oxygen Demand (COD).

\subsection{Laundry Wastewater Characterization}

The wastewater quality test results were analyzed and observed side-by-side with the wastewater standards issued in Regulation No. 7 of 2016 [11], where the highest allowable BOD and COD levels are $75 \mathrm{mg} / \mathrm{L}$ and $159 \mathrm{mg} / \mathrm{L}$, respectively (Table 2).

Table 2. Wastewater Parameter Standards for Laundry Industries

\begin{tabular}{ccc}
\hline & Industries \\
Parameters & $\begin{array}{c}\text { Maximum } \\
\text { Allowable Presence } \\
(\mathrm{mg} / \mathrm{L})\end{array}$ & $\begin{array}{c}\text { Highest } \\
\text { Pollution Loads } \\
(\mathrm{kg} / \text { ton })\end{array}$ \\
\hline \hline $\mathrm{BOD}_{5}$ & 75 & 1.5 \\
\hline $\mathrm{COD}$ & 150 & 3 \\
\hline $\mathrm{TSS}$ & 100 & 2 \\
\hline $\mathrm{TDS}$ & 2,000 & 40 \\
\hline Detergent & 5 & 0.1 \\
\hline Temperature & $\pm 3^{\circ} \mathrm{C}$ of air temperature \\
\hline $\mathrm{pH}$ & $6.0-9.0$ \\
\hline $\begin{array}{c}\text { Largest } \\
\text { wastewater } \\
\text { discharge }(\mathrm{L} / \mathrm{kg})\end{array}$ & 20 \\
\hline Source: SRY Regulation No. 7 of 2016
\end{tabular}

\subsection{Code River Water Quality Analysis}

The river water quality characteristics were compared with the SRY Government's Regulation No. 20 of 2008 [12] (Table 3), which classifies the quality based on a predefined stream order. Based on the SRY Government's Regulation No. 22 of 2007 [13], the Boyong River (upper reach of the watershed) is a firstorder stream, while the Code River (middle and lower reaches) is second-order.

Table 3. BOD and COD Standards by Stream Orders

\begin{tabular}{lrrrrr}
\hline Parameters & Units & First & Second & Third & Fourth \\
\hline \hline BOD & $\mathrm{mg} / \mathrm{L}$ & 2 & 3 & 6 & 12 \\
\hline COD & $\mathrm{mg} / \mathrm{L}$ & 10 & 25 & 50 & 100 \\
\hline
\end{tabular}

Source: SRY Government's Regulation No. 20 of 2008

\subsection{Comparative Analysis of Laundry \\ Wastewater and River Water Quality}

The relationship between laundry wastewater and Code River water quality was analyzed descriptively using tables and graphics. Code Watershed was divided into ten segments; each had a water quality observation point. These segments were also identified as experiencing point source pollution from the wastewater generated by laundry businesses. 


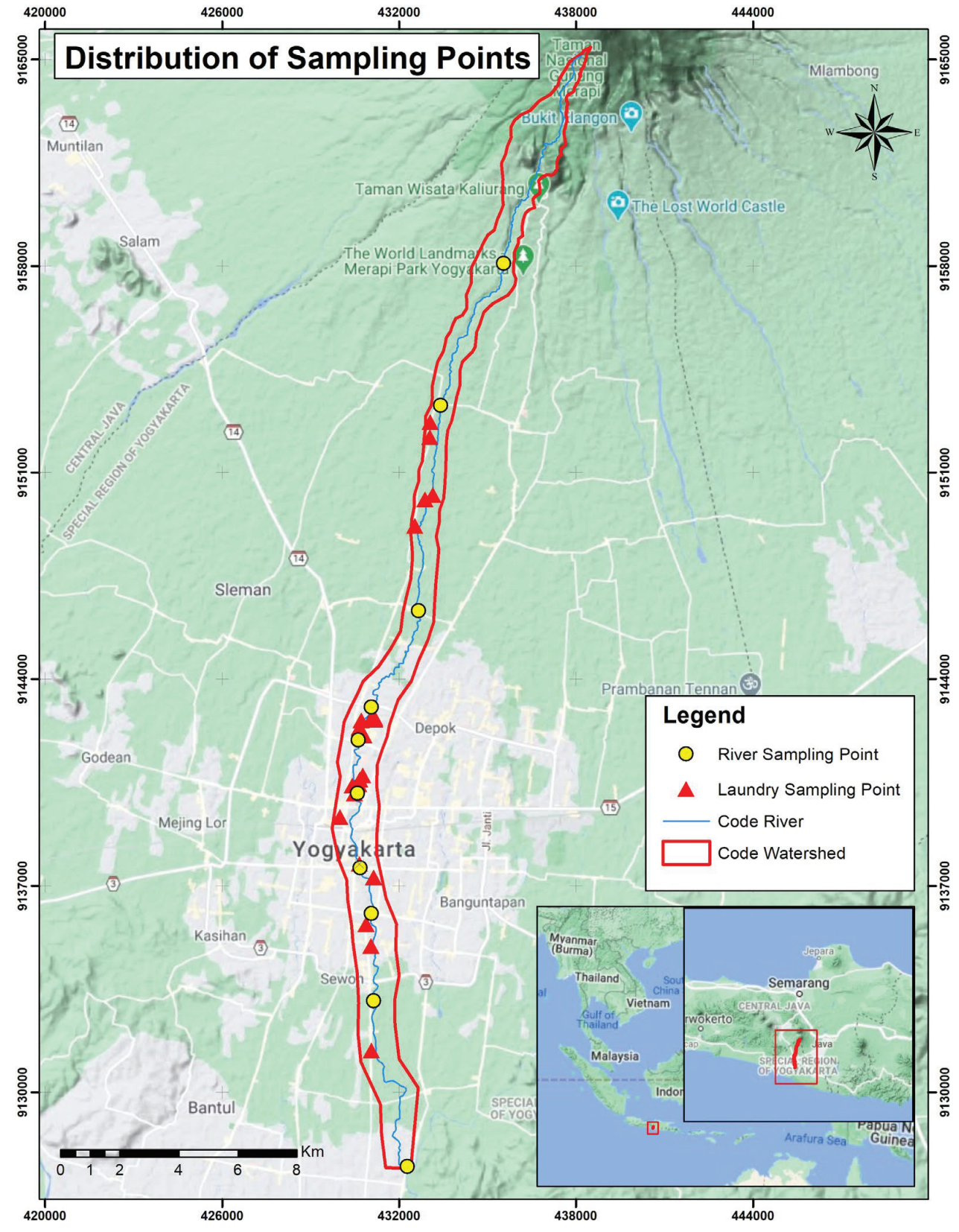

Fig 1. Water Sampling Points in the Code River

\section{Results and Discussion}

\subsection{Laundry Wastewater Characteristics}

Table 4 shows the laboratory test results of 25 laundry wastewater samples. Compared with the wastewater quality standards set in Regulation No. 7 of 2016, five samples contained high BOD levels exceeding the upper threshold, $75 \mathrm{mg} / \mathrm{L}$. These five samples were that of Rumah Cuci $(165 \mathrm{mg} / \mathrm{L})$, Malika $(93.3 \mathrm{mg} / \mathrm{L})$, Ceria $(141 \mathrm{mg} / \mathrm{L})$, Hayu $(125 \mathrm{mg} / \mathrm{L})$, and Icigo (264 $\mathrm{mg} / \mathrm{L}$ ). As indicated by the bold figures in Table 4, 18 samples had COD in the range of $136-366 \mathrm{mg} / \mathrm{L}$, exceeding the laundry wastewater quality standard, 150 $\mathrm{mg} / \mathrm{L}$.

High BOD and COD levels are in line with previous research in India that found high levels of BOD (230-626 mg/L), COD (376-910 mg/L), and suspended solids $(445-1,550 \mathrm{mg} / \mathrm{L})$ in laundry wastewater [9], and these conditions are believed to be due to the use of various detergents [14]. The interview with laundry owners revealed that cloth washing requires different types of detergents, increasing the presence of surfactants (complex organic compounds) in the liquid waste and the amount of oxygen required by 
microorganisms to break down organic matters in the water.

\subsection{Code River Water Quality}

Table 5 shows the BOD and COD levels of the Code River water samples. Sampling points S1-S3 and S4-S10 were, respectively, compared with class I and class II water quality standards issued in the SRY Government's Regulation No. 20 of 2008. Five samples contained high BOD levels exceeding the predetermined standard: S2 (Pulowatu Bridge, $2.14 \mathrm{mg} / \mathrm{L}$ ), S4 (Ring Road Utara Bridge, $6.99 \mathrm{mg} / \mathrm{L}$ ), S7 (Sayidan Bridge, $4.76 \mathrm{mg} / \mathrm{L}$ ), S8 (Lowanu Bridge, $5.63 \mathrm{mg} / \mathrm{L}$ ), and $\mathrm{S} 10$ (Kembangsong Bridge, $3.33 \mathrm{mg} / \mathrm{L}$ ). Meanwhile, the COD levels varied from 6.32 to $11.4 \mathrm{mg} / \mathrm{L}$, meaning that none of the COD in all ten river segments is above the class I and class II water quality standards.

S2 (Pulowatu Bridge), where the BOD exceeded its allowable level in class I water, is located in the upper reach of the Code River. Similarly, S4 (Ring Road Utara Bridge) is in the middle segment, i.e., the center of the economic growth in the Sleman Regency. Meanwhile, the other three sampling points (S7, S8, and S10) are located in the lower reach, and the excessively high BOD levels at these points are potentially caused by the accumulation of pollutants upstream. A previous study found that the Code River segment in Kotabaru (City of Yogyakarta) had a high BOD level, i.e., $100.1 \mathrm{mg} / \mathrm{L}$ [15], and it is located close to the lower reach of the river.

Table 4. BOD and COD Levels of the Sampled Laundry Business Wastewater in the Code River

\begin{tabular}{|c|c|c|c|c|c|}
\hline \multirow[t]{2}{*}{ No } & \multirow{2}{*}{$\begin{array}{l}\text { Laundry Business } \\
\text { Names }\end{array}$} & \multicolumn{2}{|c|}{ Coordinates } & \multicolumn{2}{|c|}{$\begin{array}{c}\text { Wastewater Quality } \\
(\mathrm{mg} / \mathrm{L})\end{array}$} \\
\hline & & $\mathrm{X}$ & $\mathrm{Y}$ & BOD & COD \\
\hline 1 & Gading Laundry & 433056.53 & 9152706.17 & 10.2 & 272 \\
\hline 2 & Nabila Laundry & 432870.02 & 9150095.37 & 13.4 & 158 \\
\hline 3 & Amanah Laundry & 433136.02 & 9150236.97 & 14.3 & 253 \\
\hline 4 & Djamil Laundry & 432537.89 & 9149194.23 & 14.3 & 136 \\
\hline 5 & Rumah Cuci Laundry & 433040.64 & 9152194.03 & 165 & 354 \\
\hline 6 & Purple Bubble Laundry & 431077.00 & 9142700.00 & 19.4 & 107 \\
\hline 7 & Medio Laundry & 431167.00 & 9142670.00 & 5.64 & 190 \\
\hline 8 & Omah Degan Laundry & 430711.05 & 9142590.74 & 27.4 & 78.8 \\
\hline 9 & Spongebob Laundry & 431179.00 & 9142616.00 & 51.6 & 392 \\
\hline 10 & Express Laundry & 431073.95 & 9142652.43 & 1.56 & 183 \\
\hline 11 & Kawankoe Laundry & 430759.00 & 9142175.00 & 6.54 & 50.6 \\
\hline 12 & Mom's Laundry & 430653.00 & 9142337.00 & 20.6 & 259 \\
\hline 13 & B \& K Laundry & 430750.00 & 9142136.00 & 14.4 & 253 \\
\hline 14 & Icigo Laundry & 430803.00 & 9142081.00 & 264 & 334 \\
\hline 15 & Pelangi Laundry & 430764.00 & 9140728.00 & 19.8 & 69.5 \\
\hline 16 & Nana Laundry & 430631.00 & 9140432.00 & 23.5 & 44.2 \\
\hline 17 & Malika Laundry & 430405.00 & 9140384.00 & 93.3 & 101 \\
\hline 18 & Laundry $31 \mathrm{C}$ & 430669.85 & 9140591.29 & 20.1 & 75.8 \\
\hline 19 & Laundry Kiloan 34 & 430492.00 & 9140124.00 & 23.8 & 171 \\
\hline 20 & Ceria Laundry & 429996.00 & 9139322.00 & 141 & 348 \\
\hline 21 & Hayu Laundry & 430650.00 & 9137731.00 & 125 & 366 \\
\hline 22 & Gangsar Laundry & 431137.00 & 9137274.00 & 41.1 & 341 \\
\hline 23 & Barokah Laundry & 430884.00 & 9135680.00 & 12.0 & 221 \\
\hline 24 & Youshan Laundry & 431050.00 & 9134953.00 & 3.98 & 240 \\
\hline 25 & Uno Fresh Laundry & 431053.00 & 9131401.00 & 70.4 & 240 \\
\hline
\end{tabular}

Source: Laboratory test results, 2020 
Table 5. BOD and COD Levels of the Sampled Water in the Code River

\begin{tabular}{clrrrrrr}
\hline \multirow{2}{*}{ Codes } & \multirow{2}{*}{ Sampling Points } & \multicolumn{2}{c}{ Coordinates } & \multicolumn{2}{c}{$\begin{array}{c}\text { Measured Parameter } \\
\text { Levels }(\mathrm{mg} / \mathrm{L})\end{array}$} & $\begin{array}{c}\text { Water Quality } \\
\text { Standard (mg/L) }\end{array}$ \\
\cline { 3 - 8 } & & X & Y & BOD & COD & BOD & COD \\
\hline \hline S1 & Gantung Boyong Bridge & 435443.24 & 9158022.7 & 0.19 & 5.69 & 2 & 10 \\
\hline S2 & Pulowatu Bridge & 433451.18 & 9153253.9 & $\mathbf{2 . 1 4}$ & 3.16 & 2 & 10 \\
\hline S3 & Kamdanen Bridge & 432545.7 & 9146251.5 & 1.33 & 9.48 & 2 & 10 \\
\hline S4 & Ring Road Utara Bridge & 431096.92 & 9143052.1 & $\mathbf{6 . 9 9}$ & 8.85 & 3 & 25 \\
\hline S5 & New UGM Bridge & 430553.64 & 9141844.8 & 0.71 & 7.58 & 3 & 25 \\
\hline S6 & Sardjito Bridge & 430674.37 & 9140154.6 & 0.71 & 10.7 & 3 & 25 \\
\hline S7 & Sayidan Bridge & 430614 & 9137619.2 & $\mathbf{4 . 7 6}$ & 7.58 & 3 & 25 \\
\hline S8 & Lowanu Bridge & 431036.56 & 9136049.7 & $\mathbf{5 . 6 3}$ & 11.4 & 3 & 25 \\
\hline S9 & Pandeyan Bridge & 431157.29 & 9132850.3 & 2.14 & 6.32 & 3 & 25 \\
\hline S10 & Kembangsongo Bridge & 432424.97 & 9127538.2 & $\mathbf{3 . 3 3}$ & 9.48 & 3 & 25 \\
\hline
\end{tabular}

Source: Laboratory test results, 2020

Table 6. BOD and COD Level Comparison of the Laundry Wastewater and River Water Samples in the Code River

\begin{tabular}{|c|c|c|c|c|c|c|}
\hline \multirow[t]{2}{*}{ No } & \multirow[t]{2}{*}{$\begin{array}{l}\text { Laundry Business } \\
\text { Names }\end{array}$} & \multicolumn{2}{|c|}{$\begin{array}{l}\text { Laundry Wastewater } \\
\text { Quality }(\mathrm{mg} / \mathrm{L})\end{array}$} & \multirow[t]{2}{*}{$\begin{array}{c}\text { Stream Section with } \\
\text { Suspected Point Source } \\
\text { Pollution }\end{array}$} & \multicolumn{2}{|c|}{$\begin{array}{l}\text { River Water Quality } \\
\text { Downstream of the } \\
\text { Laundry Wastewater } \\
\text { Outlet (mg/L) }\end{array}$} \\
\hline & & BOD & $\mathrm{COD}$ & & BOD & $\mathrm{COD}$ \\
\hline 1 & Gading Laundry & 10.2 & 272 & \multirow{5}{*}{ Kamdanen Bridge } & \multirow{5}{*}{1.33} & \multirow{5}{*}{9.48} \\
\hline 2 & Nabila Laundry & 13.4 & 158 & & & \\
\hline 3 & Amanah Laundry & 14.3 & 253 & & & \\
\hline 4 & Djamil Laundry & 14.3 & 136 & & & \\
\hline 5 & $\begin{array}{l}\text { Rumah Cuci } \\
\text { Laundry }\end{array}$ & 165 & 354 & & & \\
\hline 6 & $\begin{array}{l}\text { Purple Bubble } \\
\text { Laundry }\end{array}$ & 19.4 & 107 & \multirow{9}{*}{ New UGM Bridge } & \multirow{9}{*}{0.71} & \multirow{9}{*}{7.58} \\
\hline 7 & Medio Laundry & 5.64 & 190 & & & \\
\hline 8 & $\begin{array}{l}\text { Omah Degan } \\
\text { Laundry }\end{array}$ & 27.4 & 78.8 & & & \\
\hline 9 & Spongebob Laundry & 51.6 & 392 & & & \\
\hline 10 & Express Laundry & 1.56 & 183 & & & \\
\hline 11 & Kawankoe Laundry & 6.54 & 50.6 & & & \\
\hline 12 & Mom's Laundry & 20.6 & 259 & & & \\
\hline 13 & B \& K Laundry & 14.4 & 253 & & & \\
\hline 14 & Icigo Laundry & 264 & 334 & & & \\
\hline 15 & Pelangi Laundry & 19.8 & 69.5 & \multirow{4}{*}{ Sardjito Bridge } & \multirow{4}{*}{0.71} & \multirow{4}{*}{10.7} \\
\hline 16 & Nana Laundry & 23.5 & 44.2 & & & \\
\hline 17 & Malika Laundry & 93.3 & 101 & & & \\
\hline 18 & Laundry $31 \mathrm{C}$ & 20.1 & 75.8 & & & \\
\hline 19 & Laundry Kiloan 34 & 23.8 & 171 & \multirow{3}{*}{ Sayidan Bridge } & \multirow{3}{*}{4.76} & \multirow{3}{*}{7.58} \\
\hline 20 & Ceria Laundry & 141 & 348 & & & \\
\hline 21 & Hayu Laundry & 125 & 366 & & & \\
\hline
\end{tabular}




\begin{tabular}{|c|c|c|c|c|c|c|}
\hline \multirow[t]{2}{*}{ No } & \multirow[t]{2}{*}{$\begin{array}{l}\text { Laundry Business } \\
\text { Names }\end{array}$} & \multicolumn{2}{|c|}{$\begin{array}{l}\text { Laundry Wastewater } \\
\text { Quality }(\mathrm{mg} / \mathrm{L})\end{array}$} & \multirow[t]{2}{*}{$\begin{array}{l}\text { Stream Section with } \\
\text { Suspected Point Source } \\
\text { Pollution }\end{array}$} & \multicolumn{2}{|c|}{$\begin{array}{c}\text { River Water Quality } \\
\text { Downstream of the } \\
\text { Laundry Wastewater } \\
\text { Outlet }(\mathrm{mg} / \mathrm{L}) \\
\end{array}$} \\
\hline & & BOD & $\mathrm{COD}$ & & BOD & $\mathrm{COD}$ \\
\hline 22 & Gangsar Laundry & 41.1 & 341 & Lowanu Bridge & 5.63 & 11.4 \\
\hline 23 & Barokah Laundry & 12.0 & 221 & \multirow{2}{*}{ Pandeyan Bridge } & \multirow{2}{*}{2.14} & \multirow{2}{*}{6.32} \\
\hline 24 & Youshan Laundry & 3.98 & 240 & & & \\
\hline 25 & Uno Fresh Laundry & 70.4 & 240 & Kembangsongo Bridge & 3.33 & 9.48 \\
\hline
\end{tabular}

Notes: bold figures indicate exceeded quality standards

\subsection{Comparison between Laundry Wastewater and River Water Quality}

Table 6 shows the spatial distribution of the wastewater and river water quality samples at seven sampling points: S3 (Kamdanen Bridge), S5 (New UGM Bridge), S6 (Sarjito Bridge), S7 (Sayidan Bridge), S8 (Lowanu Bridge), S9 (Pandeyan Bridge), and S10 (Kembangsongo Bridge). Fig. 3 and Fig. 4 illustrate the distribution of BOD and COD levels of the laundry wastewater and Code River water quality. Nearly all of the wastewater samples showed that BOD and COD decreased downstream when Boyong River reaches Code River. Spatially, in the Kamdanen Bridge segment, there was a waste input from five laundry businesses, with BOD levels varying from 10.2 to $165 \mathrm{mg} / \mathrm{L}$ and COD in the range of $136-354 \mathrm{mg} / \mathrm{L}$. At the point where Boyong River stops and continues as Code River, the BOD and COD levels lowered to $1.33 \mathrm{mg} / \mathrm{L}$ and 9.48 $\mathrm{mg} / \mathrm{L}$, below the class 2 river water quality standards.

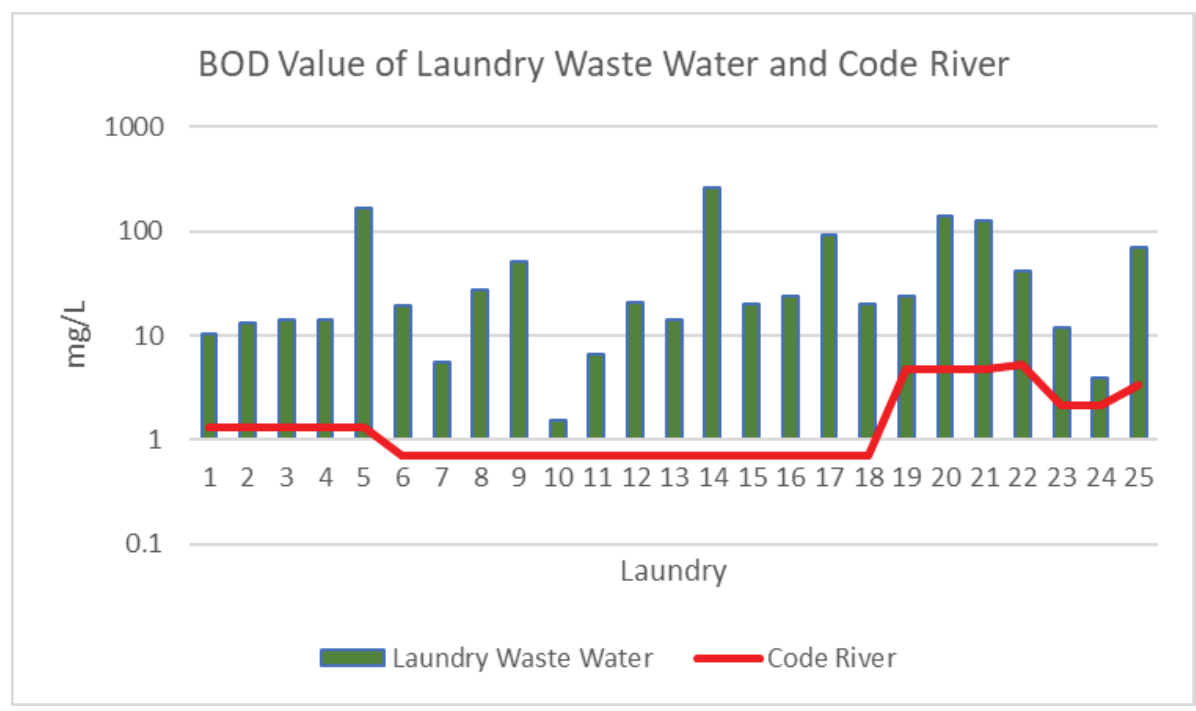

Fig 2. BOD Levels of Laundry Business Wastewater and Code River Water (25 Samples) 


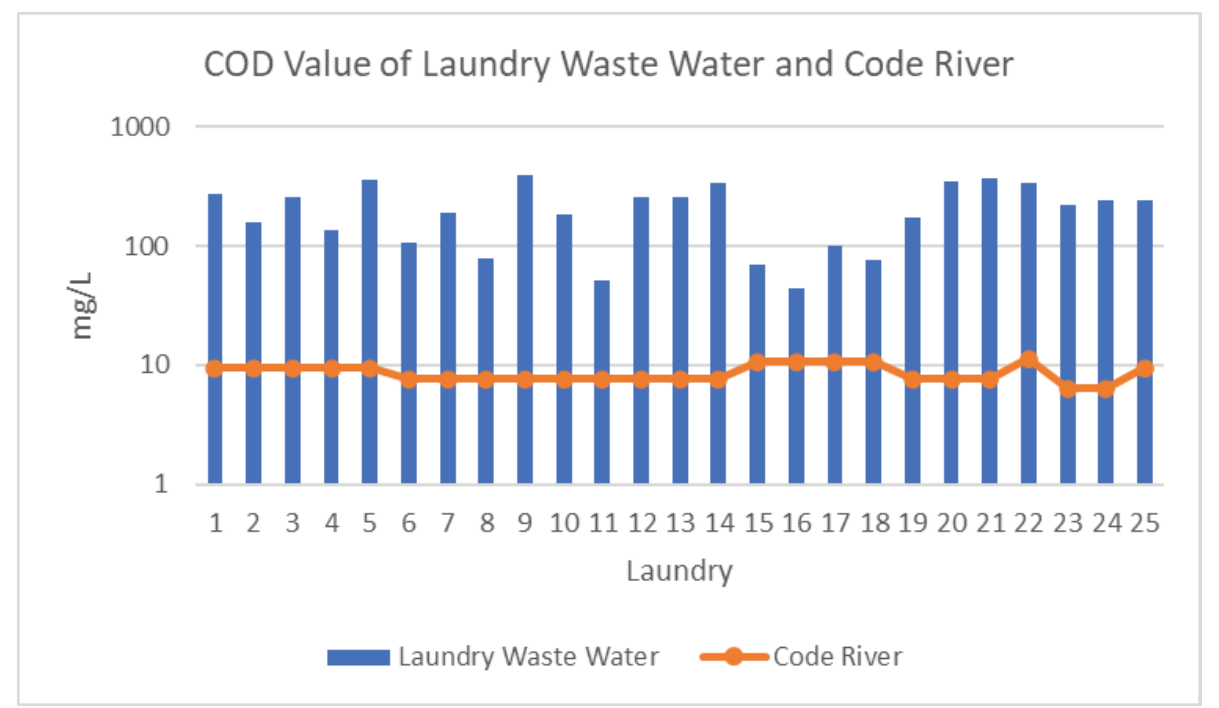

Fig 3. COD Levels of Laundry Business Wastewater and Code River Water (25 Samples)

S5 (New UGM Bridge segment) received waste input from nine laundry businesses and, therefore, had BOD in the range of $1.56-264 \mathrm{mg} / \mathrm{L}$ and COD between 50.6 and $392 \mathrm{mg} / \mathrm{L}$. At the point where Boyong continues as Code River, the BOD and COD lowered to $0.71 \mathrm{mg} / \mathrm{L}$ and $7.58 \mathrm{mg} / \mathrm{L}$, respectively, below the class II river water quality standard. The same case applies to S6 (Sardjito Bridge segment), which received wastewater from four laundry businesses; BOD and COD levels decreased from $19.8-93.3 \mathrm{mg} / \mathrm{L}$ and $44.2-75.8 \mathrm{mg} / \mathrm{L}$ to $0.71 \mathrm{mg} / \mathrm{L}$ and $10.7 \mathrm{mg} / \mathrm{L}$, below the quality standards. Three laundry businesses disposed of their wastewater in S7 (Sayidan Bridge segment), leading to high BOD $(23.8-141 \mathrm{mg} / \mathrm{L})$ and COD $(171-366 \mathrm{mg} / \mathrm{L})$ that later decreased to $4.76 \mathrm{mg} / \mathrm{L}$ and $7.58 \mathrm{mg} / \mathrm{L}$, respectively, where the Code River channel begins. At this point, the BOD is still above the specified river water quality standard, while the COD is below it.

S8 (Lowanu Bridge segment) received waste input from one laundry business, and like the previous three sampling points, its BOD and COD lowered from 41.1 $\mathrm{mg} / \mathrm{L}$ and $341 \mathrm{mg} / \mathrm{L}$ to $5.63 \mathrm{mg} / \mathrm{L}$ and $11.4 \mathrm{mg} / \mathrm{L}$, respectively, where the Code River channel starts. These BOD levels are above the predetermined standard. The same case applies to S9 (Pandeyan Bridge segment) that received wastewater from two laundry businesses; BOD and COD levels decreased from $3.98-12.0 \mathrm{mg} / \mathrm{L}$ and $221-240 \mathrm{mg} / \mathrm{L}$ to $2.14 \mathrm{mg} / \mathrm{L}$ and $6.32 \mathrm{mg} / \mathrm{L}$. One laundry business discharged its wastewater into S10 (Kembangsongo Bridge segment), leading to high BOD $(70.4 \mathrm{mg} / \mathrm{L})$ and COD $(240 \mathrm{mg} / \mathrm{L})$ that later decreased to $3.3 \mathrm{mg} / \mathrm{L}$ and $9.48 \mathrm{mg} / \mathrm{L}$, respectively, where Boyong continues as Code River. The BOD levels in this segment have exceeded the predefined class II river water quality standard.

\section{Conclusion}

The wastewater disposed of laundry businesses around the Code River has high levels of BOD and COD at several sampling points because the various detergents used in cloth washing elevate the amount of oxygen needed by microorganisms to break down organic matter. Based on the Code River water quality test results, the BOD at some sampling points has exceeded its allowable level in river water, but the COD is below the predetermined quality standard. The point at which Boyong River stops and Code River channel starts is marked by lowered BOD and COD levels because of many factors. Further research is required to explain this relationship in more detail.

\section{Acknowledgment}

The authors would like to thank Universitas Gadjah Mada for financially assisting this research through the Thesis Recognition Grant (Hibah Rekognisi Tugas Akhir) in the fiscal year of 2020.

\section{References}

1. Widodo, B., Kasam, Ribut L, and Ike A. Strategi penurunan pencemaran limbah domestik di Sungai Code DIY. Jurnal Sains dan Teknologi Lingkungan, vol 5 (1): 36-47 (2013)

2. Dinas Lingkungan Hidup Kota Yogyakarta (DLHK). Kajian Beban Pencemaran Sungai Code Tahun 2018. 92 (2018)

3. Puspitasari, Dinarjati Eka. Dampak pencemaran air terhadap kesehatan lingkungan dalam perspektif hukum lingkungan (studi kasus Sungi Code di Kelurahan Wirogunan, Kecamatan Mergangsan dan Kelurahan Prawirodirjan Kecamatan Gondomanan Yogyakarta). Mimbar Hukum, Vol 21 (1): 23-34 (2009)

4. Wendland, C., \& Albold, A. Sustainable and costeffective wastewater systems. 19 (2010)

5. Ciabattia, I., Cesaro, F., Faralli, L., Fatarella, E., \& Tognotti, F. Demonstration of a treatment system for purification and reuse of Laundry wastewater. 
Desalination, 245(1-3), 451-459. https://doi.org/10.1016/j.desal.2009.02.008 (2009)

6. Agarwal, A. Water pollution problems posed by small industries: A case study of India and China. Water Science and Technology, 45(8), 47-52. https://doi.org/10.2166/wst.2002.0142 (2002)

7. Lade, O., \& Zainab, G. Potential of recycling laundry wastewater for domestic use. Journal of Civil Engineering and Sustainable Water Supply, 4, 56-60 (2018)

8. Braga, J. K., \& Varesche, M. B. A. Commercial Laundry Water Characterisation. American Journal of Analytical Chemistry, 05(01), 8-16. https://doi.org/10.4236/ajac.2014.51002 (2014)

9. Sheth, K. N., Patel Mittal., \& Desai, M. D. A study on characterization \& treatment of Laundry effluent. International Journal for Innovative Research in Science \& Technology Vol 4 (1): 5055 (2017)

10. Ardiyanto, Putra., and Yuantari, Maria G.C. Analisis limbah Laundry informal dengan tingkat pencemaran lingkungan di Kelurahan Muktiharjo
Kidul, Kecamatan Pedurungan Semarang. Jukung Jurnal Teknik Lingkungan vol 2 (1): 1-12 (2016)

11. Regulation of the Special Region of Yogyakarta No. 7 of 2006 on Wastewater Quality Standards (2006)

12. Regulation of the Governor of the Special Region of Yogyakarta No. 20 of 2008 on Water Quality Standards (2008)

13. Regulation of the Governor of the Special Region of Yogyakarta No. 22 of 2007 on Stream Order Determination of the Special Region of Yogyakarta (2007)

14. Watiniasih, N. L., Purnama I. G. H., Padmanabha, G., Merdana, I.M., Antara I. N. G. Managing Laundry wastewater. IOP Conference Series: Earth and Environmental Science 248012084. doi:10.1088/1755-1315/248/1/012084 (2018)

15. Widyasari, Titiek. Beban pencemaran sumber limbah di Sungai Code. Jurnal Teknik Sipil Vol 5 (2): 93-169 (2009) 